Research paper

\title{
Haritava maa mahajätmine Tartu maakonnas
}

\author{
Merit Mandel $^{1, *}$, Siim Maasikamäe ${ }^{1}$ ja Mait Lang ${ }^{2,3}$
}

Mandel, M., Maasikamäe, S., Lang, M. 2019. Land abandonment in Tartu County. - Forestry Studies | Metsanduslikud Uurimused 71, 30-47, ISSN 1406-9954. Journal homepage: http:/ / mi.emu.ee/forestry.studies

\begin{abstract}
Land abandonment studies have drawn scientists' attention for more than a decade. Under the conditions of a growing world population and pressure to preserve the environment, there are still areas which are abandoned. Land abandonment occurs also in Estonia. The aim of the study is to assess the impact of the arable land plot features on the probability that land abandonment will occur on those plots. The occurrence of the brushwood on the arable land plots was used as the indicator that some areas of those plots are abandoned. The area of the plot, compactness, soil productivity, ratio of ameliorated land, roughness of land and the distance to the different objects were used for the description of the arable land plots. The study area covered Tartu County in Estonia and was based on the combination of the Estonian National Topographic Database vector data and land cover height model raster data provided by the Estonian Land Board. The study period covered the timeframe from 2011 to 2017 and consisted of 6,604 agricultural plots. The plots were divided into two groups (without and with brushwood) and the mean values of the indicators describing the features of the arable land plots were calculated for the groups. The binominal logistic regression analysis was also used to assess the potential (probability) of plots to be abandoned. Results of the study showed that the features of the arable land plots have an impact on the probability that land abandonment will occur on those plots.
\end{abstract}

Key words: land abandonment, spatially explicit variables, agriculture, land use change.

Authors' addresses: ${ }^{1}$ Chair of Geomatics, Institute of Forestry and Rural Engineering, Estonian University of Life Sciences, Kreutzwaldi 5, 51006 Tartu, Estonia; ${ }^{2}$ Tartu Observatory, Faculty of Science and Technology, University of Tartu, 61602 Tõravere, Tartumaa, Estonia; ${ }^{3}$ Chair of Forest Management Planning and Wood Processing Technologies, Institute of Forestry and Rural Engineering, Estonian University of Life Sciences, Kreutzwaldi 5, 51006 Tartu, Estonia; *e-mail: merit.mandel@mail.ee

\section{Sissejuhatus}

Eesti põllumajandus on läbinud mitu suurt struktuurilist muutust. Kui 1919. aasta maareformi eesmärk oli luua väikemaaomand, siis 1944-1947. a maareformi käigus kujundati taas maasuhted ümber ning algas põllumajanduse kollektiviseerimine (Virma, 2004). Põllumajanduse ja tootmise koondumisega aastail 1950-1990 vähenes põllumajandusliku maa pindala 1 miljoni hektari võrra 1,5 miljoni hektarini ja suurenes metsa pindala 900000 hektari võrra 1,9 miljoni hektarini (Virma, 2004). 
Järgmine suurem muutus Eesti põllumajanduslikus maakasutuses algas 90-ndate alguses, kui Nõukogude Liit lagunes ning algas maade tagastamine ja erastamine. Maareformi käigus tagastati natsionaliseeritud maa õigusjärgsetele omanikele või nende õigusjärglastele, kuid paljud neist ei olnud põllumajandusega seotud ning neil puudusid oskused ja vahendid, et tegeleda põllumajandusega pärast kolhooside ja sovhooside lagunemist. Hinnanguliselt oli 1993. aastaks kasutusest väljas 20-30\% haritavast maast (Peterson \& Aunap, 1998). Teine suurem muutus põllumajanduslikus maakasutuses toimus 2000-ndate alguses, kui Eesti liitus Euroopa Liiduga. Selle liitumise järel avanes Eesti põllumeestel võimalus osa saada põllumajandustoetustest Euroopa Liidu ühise põllumajanduspoliitika raames. Toetuste eesmärk on tõsta põllumajanduslikku tootlikkust tehnilise progressi teel, samas jättes tarbijahinnad mõistlikuks ja tagada põllumajandustootjate rahuldav elatustase (Massot, 2019). Samal ajal tuli Eesti põllumajandusel konkureerida kinnisvara- ja infrastruktuuriarendustega põllumajandusmaadel. Kinnisvaraarenduse tulemusena võib väheneda põllumaa kompaktsus, mis võib mõjutada selle edaspidist kasutamist (Veeroja et al., 2013; Heil \& Maltis, 2015). Tartu maakonna kontekstis on suurimad muutused toimunud endises Ülenurme vallas (enne 2017. aasta haldusreformi), kus aastatel 2005 kuni 2016 vähenes rohumaa pind 87 hektari võrra ning õuede ja teede alune pind kasvas 160 ja 24 hektari võrra vastavalt (Ritsoson, 2016). Eesti Statistikaameti andmetel on kasutamata põllumajandusmaa pind aastatega vähenenud, kuid mitte täielikult kadunud. 2001. aastal oli kasutusest väljas oleva põllumajandusmaa pindala 73961 ha, 2003. aastal 60025 ha, 2005. aastal 45 647 ha, 2007. aastal 31819 ha ja 2010. aastal 26097 ha (Eesti Statistika Andmebaas, 2011).

Maakasutuse muutus üldiselt ja eelkõige põllumajandusliku maa mahajätmine on keerulised ruumilised protsessid
(Levers et al., 2018). Tegureid, mis võivad viia maade mahajätmisele, on hulgaliselt. Asukohast lähtuvad tegurid - kaugus teedest, metsa servast, lähimast asulast/ keskusest (Prishchepov et al., 2013); põllu omadused - pindala, kompaktsus, mulla pH+ (Zaragozí et al., 2012); sotsiaalmajanduslikud - nõrk maa turg, talu madal sissetulek, talu suurus, talupidaja vanus, põllumajanduse madal oskustase (Terres et al., 2015). Sarnased tegurid võivad olenevalt piirkondadest viia erinevate muutusteni. Näiteks tegurid, mis ühes piirkonnas viivad maa mahajätmisele, võivad teises piirkonnas viia hoopis haritava maa pindala suurenemisele. Linna lähiümbrusesse jääv hea juurdepääsetavusega põld võib tiheda liikluse ja aktiivse majandustegevuse tõttu jääda põllumajanduslikust kasutusest välja, kuid kui maapiirkonnas muudetakse kohalik tee kehvadele ilmastikuoludele vastupidavamaks ning rasketele masinatele läbipääsetavamaks, võib mõni varem võsastunud ala leida jälle põllumajanduslikku kasutust. Lisaks võib esineda piirkondi, kus samal ajal haritava maa võsastumisega võetakse kasutusele ka uued haritavad alad (Hatna \& Bakker, 2011). Protsentides ei muutu midagi, kuid võib muutuda võsastunud põldude asukoht. Seetõttu peab maakasutuse muutuste analüüs olema asukohaspetsiifiline ning arvestama erinevate teguritega ja muutumissuundadega (Verburg et al., 2010). Põllumajandus areneb pidevalt, võetakse kasutusele uusi maaharimise meetodeid (nt otsekülv) ja suuremaid seadmeid. Kaasaegse tehnika kasutamine väikestel ja keerulise kujuga põldudel võib olla problemaatiline (MacDonald et al., 2000; Gellrich \& Zimmermann, 2007; Cramer et al., 2008). See võib kaasa tuua põllumaa ülemineku rohumaaks, millele võib järgneda täielik mahajätmine ja võsastumine.

Eestis on suur osa haritavast maast praeguseks koondunud suurtootjate kätte (Rasva, 2017). See võib kaasa tuua väiksemate, korrapäratu kuju ja kehva ligipääsetavusega maatükkide põllumajanduslikust 
kasutusest väljajätmise ja ka nende võsastumise. Kuid juba võsastunud maa muutmine tagasi põllumaaks on ressursimahukas protsess (Larsson \& Nilsson, 2005) ja seda võib mõjutada aeg, kui kaua põld on olnud maha jäetud või kui palju on sellel puittaimestikku kasvanud (Alcantara et al., 2013). Kasutusest välja jäänud põldudele hakkab teatud aja möödudes kasvama puittaimestik, esialgu võsa ja hiljem võib see muutuda ka juba metsaks. Seega näitab põldudel kasvav puittaimestik, et kogu põld või teatud osa sellest on maha jäetud. Siinses töös on kasutatud mõisteid "võsa“ ja "võsastumine", tähistamaks igasugust põldudel olevat puittaimestikku.

Uurimistöö eesmärk on hinnata põllumassiivide mulla viljakuse, ruumiliste omaduste ja asukoha võimalikku mõju haritava maa mahajätmisele. Hüpotees on, et mida väiksema viljakusega, halvemate ruumiliste omadustega ja asukohaga on põllumassiiv, seda suurem on tõenäosus, et põldudel esineb võsastunud alasid.

Uurimistöö eesmärgi täitmiseks analüüsiti seoseid haritava maa massiivide võsastumise ulatuse ja nende massiivide omaduste vahel. Massiivide omaduste iseloomustamiseks kasutati järgmisi näitajaid - põllumassiivi pindala; põllumassiivi kaalutud keskmine boniteet; põllumassiivi kompaktsus; põllumassiivi pinna keskmine konarlikkus (pinna ebakorrapärasuse aste, mis iseloomustab põllu mikroreljeefi); maaparandusega ala osatähtsus põllumassiivi pindalast; kaugus Tartust; kaugus lähimast asulast (alev, linn); kaugus lähimast riigiteest; kaugus lähimast naaberpõllumassiivist.

Uurimistöö tehti Tartu maakonna näitel ja haritava maa massiivide määramiseks kasutati Eesti Topograafilise Andmekogu (edaspidi ETAK) andmeid. Võsastunud alade väljaselgitamiseks kasutati Maa-ameti taimkatte kõrgusmudelit. Lisaks kasutati uurimistöös Maa-ameti asustusüksuste kaarti, mullastiku kaarti ja maaparandussüsteemide piiride kaarti.

\section{Materjal ja metoodika}

\section{Uuringuala}

Uuringu alaks on Tartu maakond, milles on haritava maa osakaal üks Eesti suurimaid. Eesti keskmine haritava maa osakaal on ca $25 \%$. Tartu maakonnas on vastav näitaja ca 32\%. Tartu maakonna pindala oli 2017. a seisuga 299301 ha. Haritavat maad oli kokku 95428 hektarit. Uuringust jäi välja 1886hektarine ala maakonna põhjaosas (ligikaudu 0,6\% kogu maakonna pindalast) kuna selle ala kohta puudusid aeropildistamise ja laserskaneerimise andmed 2017. aasta seisuga.

Tartu maakonnas elas 2017. aastal 145550 inimest (Eesti Statistika Andmebaas, 2017). Maakonnas oli 2017. aasta aprilli seisuga kolm linna (Tartu, Elva ja Kallaste) ning 19 valda (Statistikaamet, 2017). 2017. aastal oli põllukultuuride kasvupind kokku 76321 ha, millest 52\% moodustas teravili, $18 \%$ mitmeaastased söödakultuurid, 13\% kaunviljad ja 12\% tehnilised kultuurid (Maa-amet, 2018a).

\section{Metoodika}

Esimeses etapis (joonis 1) koostati uuritavate põllumassiivide (edaspidi: põllud) digitaalkaart. Teises etapis määrati laserskaneerimise andmetest põldudel olevad võsastunud alad. Selle etapi tulemusena leiti iga põllu kohta võsastunud alade osakaal protsentides. Kolmandas etapis toimus põllumassiivide ruumiliste omaduste (suurus, kuju jm) iseloomustamine. Neljandas etapis uuriti statistiliste meetoditega seoseid põldude ruumiliste omaduste ja põldudel olevate võsastunud alade osatähtsuse vahel.

\section{1. etapp - Põllumassiivide digitaalkaardi loomise protsess}

Põllumaa kasutuses toimuvate muudatuste väljaselgitamiseks moodustati põllumaa kontuurid (põllumassiivid) 2011. aasta seisuga. Selleks kasutati ETAK-i 2011. aasta haritava maa kaardikihti, millest eraldati põllumaa kontuurid, välja jäid aiandusliku maa 
I etapp

Põllumassiivide kaardi koostamise protsess

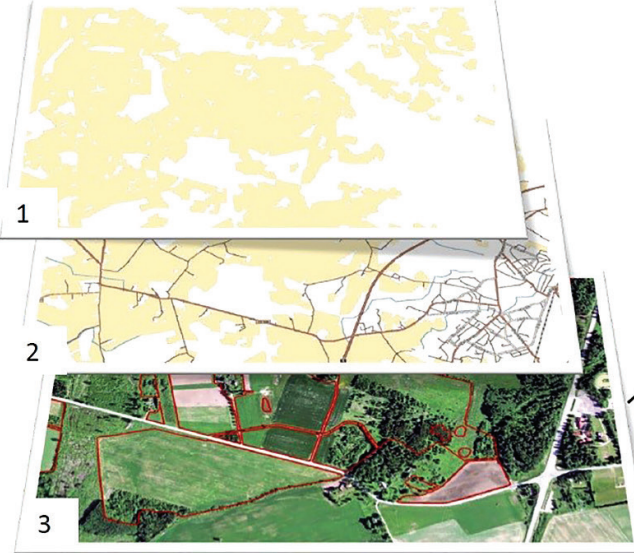

II etapp

Võsastunud alade kaardi koostamise protsess
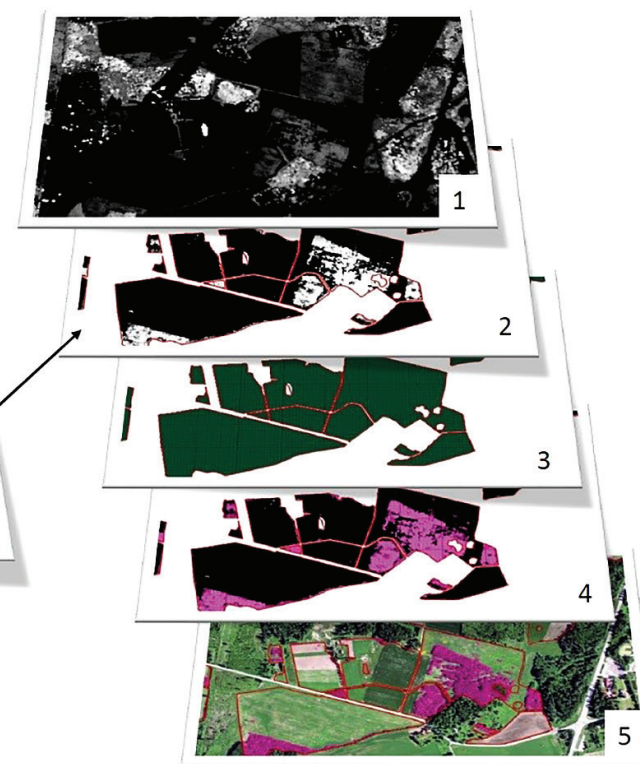

Joonis 1. Digitaalkaartide koostamise etapid.

\section{Figure 1. Processing steps of digital map construction.}

kontuurid, kuna nendel maatükkidel võib esineda viljapuid (Topograafilised andmed, 2014; § $27 \lg 2$ ). Välja jäeti ka linnades ja alevikes olevad alad (I etapp, kaart 1 , joonis 1 ).

Joonobjektide eraldamiseks põllumaa kontuuridest moodustati joonobjektidena kaardil kujutatud teede, vooluveekogude ja puuderidade ümber puhvertsoonid (I etapp, kaart 2, joonis 1). Pärast joonobjektide alla jäävate puhvertsoonide väljalõikamist tekkisid kildpolügoonid. Need on näiteks ribad teede ja kraavide vahel. Selliste ribade elimineerimiseks moodustati põllukontuuridele neljameetrise raadiusega negatiivsed puhvrid. Järgnevalt moodustati negatiivsete puhvertsoonide ümber puhvertsoonid raadiusega neli meetrit. Selle tulemusena saadud põldudel (I etapp, kaart 3, joonis 1) oli üldjoontes nende esialgne pindala ja kuju, kuid puudusid kitsad ribad, mis tegelikkuses ei eksisteeri. Selle tulemusena vähenes kõigi uuritud põldude kogupindala uuritaval alal 0,07\% ja keskmiselt vähenes ühe põllu pindala $0,24 \%$. Tuleb arvestada, et pindala vähenemine toimus just nendel põldudel, kus kadusid ära eelnimetatud kaardil olevad ribad, mida tegelikkuses ei eksisteeri. Ligikaudu pooltel uuritud põldudest oli pindala vähenemine alla $0,1 \%$.

Allesjäänud põldude hulgast eemaldati põllud, mille pind oli alla 0,3 ha. Sellise suurusepiirangu aluseks on Põllumajanduse Registrite ja Informatsiooni Ameti (PRIA) poolt kasutatav minimaalne põllu pind, millele saab toetust taotleda (Toetused, 2015). Selle tulemusena jäi edaspidisesse töösse 6604 põldu kogupindalaga 84570 hektarit. PRIA põllumassiivide kaarti antud uurimistöö raames kasutada ei saa, sest sellel kaardil on võsastunud alad juba välja jäetud ja seega ei kajasta kaart maakasutuses toimunud muutusi. Lisaks sellele on põlde, mis ei kajastu PRIA põllumassiivide kaardil, kuid 2011. aastal olid nad ETAK-i andmetel põllud. 
2. etapp - Võsastunud alade digitaalkaardi loomise protsess

Algandmeteks olid Maa-ameti taimkatte kõrgusmudeli (CHM) andmed GeoTIFF vormingus, mis on koostatud 2017. aasta suvel toimunud aerolaserskaneerimise andmetest (II etapp, kaart 1, joonis 1). Piksli suurus maapinnal on neli meetrit. Kokku oli uurimisala kohta $47 \mathrm{CHM}$ faili, igaüks ulatusega 10×10 kilomeetrit. Mudeli piksli väärtuse arvutamisel on kasutatud 90 protsentiili väärtust. Iga piksli sisse arvutatakse LiDAR punktidest kõrgusjaotus. Kõrgusjaotusest võetakse 90\% väärtus, mis omistatakse piksli väärtuseks ning mis näitab taimestiku kõrgust selle piksli sees. (Maa-amet, 2018b)

Kõik eelnimetatud GeoTIFF failid ühendati ArcGIS keskkonnas korraldusega Mosaic To New Raster üheks failiks. Saadud rasterkaardist eraldati põllukontuuride alla jäävad alad (II etapp, kaart 2, joonis 1), selleks rakendati ArcGISis korraldust Extraction By Mask. Maskina kasutati esimeses etapis koostatud põldude kaardikihti. Selle tulemusena tekkis uus rasterkaart, kus kõigile maskist väljapoole jäänud pikslitele omistati väärtused ND (No Data). Järgnevalt teisendati saadud rasterkaart vektorkaardiks, kus iga piksli tsentrisse moodustati punktobjekt ja andmetabelisse kirjutati vastava piksli väärtus [grid code]. Pikslite keskpunktid seoti ruumipäringuga põllumassiivide kaardiga, et koos saaks analüüsida põllumassiive ja taimkatte kõrgusandmeid (II etapp, kaart 3 , joonis 1). Päringuga eraldati punktid, mille väärtus oli suurem kui null ning moodustati uus punktobjektide fail, milles oli 3987087 objekti (II etapp, kaart 4, joonis 1). Nendest 3987087 punktist olid 3062 536 punkti põldude sees nii, et asusid põllu servast vähemalt nelja meetri kaugusel (II etapp, kaart 5, joonis 1). Punktid, mis olid põldude ääres kuni neljameetrises tsoonis, jäid edasisest analüüsist välja. Selleks oli kaks põhjust. Esiteks, puude ja põõsaste kasvamine põldude servas ei tähenda veel, et tegemist on maa mahajätmisega. Teiseks, võrreldes ortofotosid ja laserskaneerimisega leitud üle 1,3 m kõrgusega puittaimestikuga alasid visuaalselt, ilmnes teatud juhtudel umbes ühe piksli suurune $(4 \mathrm{~m})$ nihe ortofotodel olevate taimkattega alade ja laserskaneerimisega määratud alade vahel. Kuna põldude ääred on erinevatel põhjustel võsastumise seisukohast ebaselged alad, siis ei arvestatud nelja meetri laiuses tsoonis olevaid punkte võsastunud aladeks, kuigi laserskaneerimise andmed sellele viitasid.

Ortofotode ja laserskaneerimise andmete esmane visuaalne võrdlemine tõi välja elektriliinidega, eriti kõrgepingeliini-
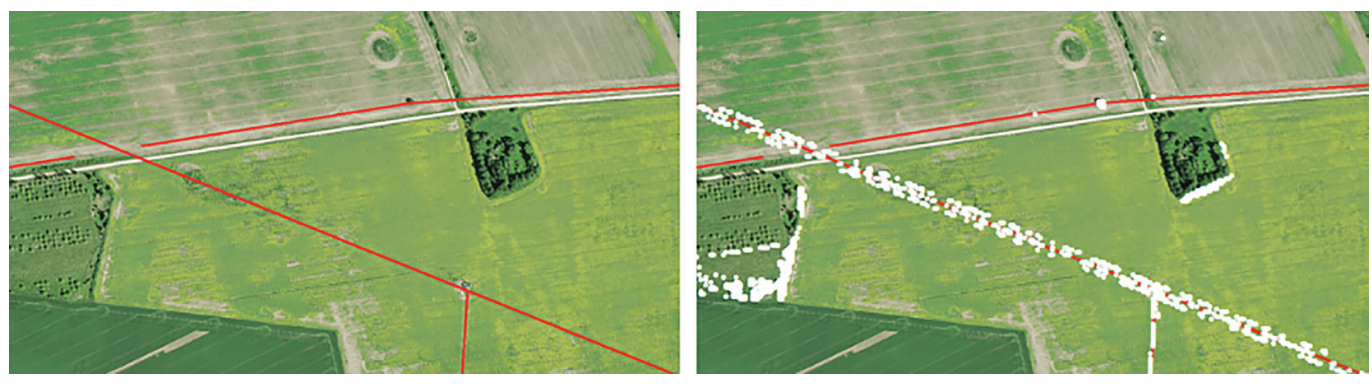

Joonis 2. Joonise vasakpoolsel osal on punase joonega tähistatud elektriliinid. Joonise parempoolsel osal on valgete punktidega tähistatud laserskaneerimisega tuvastatud maapinnast kõrgemad objektid.

Figure 2. The left part of the figure shows power lines marked with a red line. The right-hand part of the figure shows objects above the ground detected by laser scanning and marked with white dots. 
dega seotud probleemi. Suurte liinide korral tuvastatakse süstemaatiliselt traate kui maapinnast kõrgemaid objekte (joonis 2).

Elektriliinidega seotud probleem on eriti märgatav pingega 110 ja 330 kV kõrgepingeliinide korral. Suurte liinide korral, kus traatide vahe on suur, on märgatav, et iga traat moodustab omaette pikslite rea. Probleemi lahendamiseks leiti ruumilise päringu abil elektriliinide mõjutsoonis olevad niinimetatud valetaimkatte alad ja need punktid eemaldati edasisest töötlusest. Elektriliinide asukohad määrati ETAKi andmete alusel (seisuga 1.07.2018), arvestati ainult liinidega, mille nimipinge oli vähemalt $15 \mathrm{kV}$. Mõjutsoonide ulatused liinide pingest lähtudes on vastavalt $6 \mathrm{~m}$ $15-20 \mathrm{kV}, 8 \mathrm{~m} 35 \mathrm{kV}, 10 \mathrm{~m} 110 \mathrm{kV}$ ja $15 \mathrm{~m}$ $330 \mathrm{kV}$.

Kokku jäeti seoses elektriliinidega edaspidisest andmetöötlusest välja 17483 kõrguspunkti. Lisaks eemaldati käsitsi valiku alusel 371 punkti. Probleem oli selles, et Tartu juures on ETAKi andmetes üks 330 $\mathrm{kV}$ liinilõik puudu.

Selleks, et hinnata laserskaneerimisega saadud andmete kasutamise usaldusväärsust võsa tuvastamiseks põldudel, võrreldi laserskaneerimisega saadud võsastunud alade osatähtsust põldudel ja ortofotodelt visuaalselt määratud võsastunud alade osatähtsust. Võrdlus viidi läbi kolme kaardilehe $(54864 ; 54673$ ja 54534) ulatuses. Nimetatud kaardilehtede ulatuses valiti välja kõik põllud, mis olid tervikuna vastavatel kaardilehtedel. Kasutades 2017. aastal toimunud aeropildistamise andmeid, digitaliseeriti põldude piires võsastunud alad. Seejuures kasutati tavalisi RGB (Red, Green, Blue) värvikanalitega fotosid ja valevärvi CIRi (Color-infrared) fotosid.

Erinevate meetoditega leitud võsastunud alade osatähtsuse omavaheline seos (joonis 3) oli lineaarne ning väga tugev

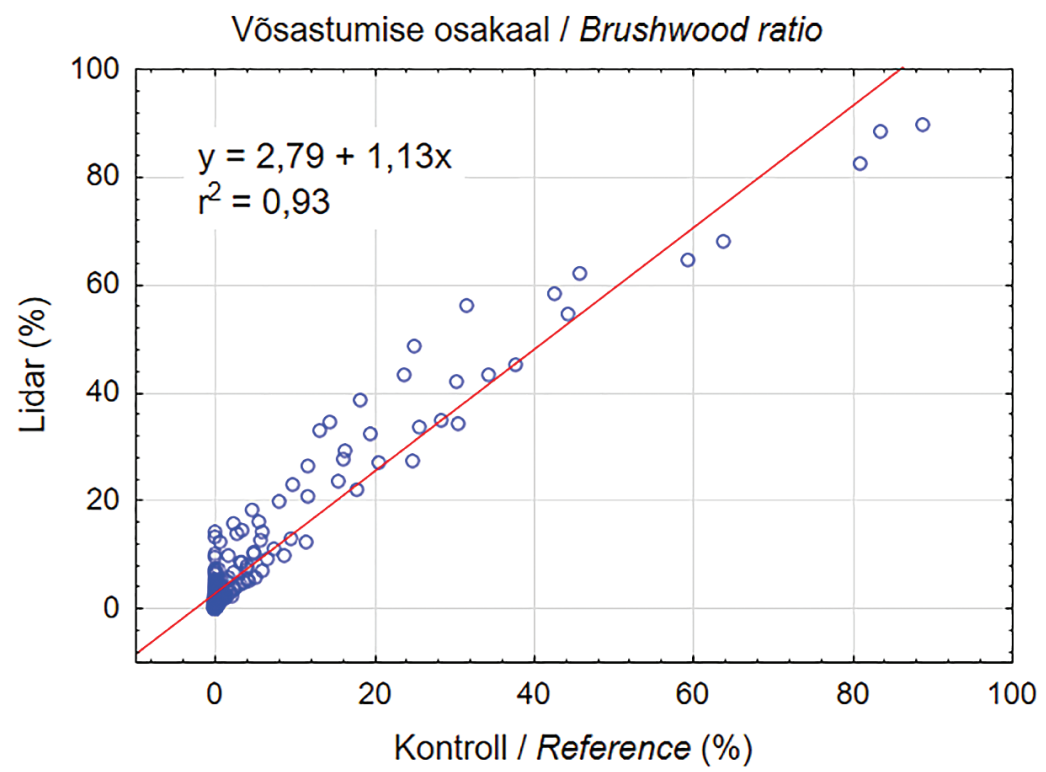

Joonis 3. Kahe erineva meetodiga määratud võsastunud alade vaheline korrelatsioon. X-teljel on ortofotodelt visuaalselt määratud võsastunud alade osatähtsus ja Y-teljel laserskaneerimisega saadud võsastunud alade osatähtsus põldudel.

Figure 3. Correlation between two different scrubland determination methods. The $x$-axis shows the ratio of the scrubland determined by visual inspection of orthophoto maps and the $y$-axis shows the ratio of the scrubland detected by laser scanning in fields. 
$\left(R^{2}=0,93\right)$. Saadud tulemus näitab, et laserskaneerimise andmetel koostatud taimkatte kõrgusmudelit saab kasutada võsastunud alade tuvastamiseks põldudel.

Seega näitab seos, et laserskaneerimise teel on võimalik tuvastada põldudel võsastunud alasid. Enamikul uuritud põldudest on võsaga kaetud alade osatähtsus alla $20 \%$ põllu pinnast. Olulist mõju avaldavad hinnangutele põldude servades olevad vaatlused, mida võivad mõjutada kontrollandmestiku ja Lidari andmestiku erinev resolutsioon $(25 \mathrm{~cm}$ vs $4 \mathrm{~m}$ piksel) ning puittaimestikuga alade asukohtade erinevused erinevatel kaartidel (ETAK ja taimkatte kõrgusmudel).

\section{3. etapp - Pôldude ruumiliste omaduste (suurus, kuju jm) iseloomustamine}

Tuginedes eelnevale uurimustööle Filho $e t$ al. (2017) seoses maade mahajätmise põhjuste ja võimalike tagajärgedega, analüüsiti järgmisi põldude omadusi iseloomustavaid näitajaid:

- põllu pindala;

- põllu kuju iseloomustav kompaktsuse koefitsient;

- mulla keskmine boniteet;

- maaparandussüsteemidega maa osatähtsus põllul;

- põllu kaugus Tartu linnast kui maakonna keskusest;

- põllu kaugus lähimast asulast;

- põllu kaugus lähimast riigiteest;

- põllu kaugus lähima naaberpõlluni;

- põllu konarlikkuse indeks.

Põllu kuju iseloomustav kompaktsuse koefitsient $\left(K_{K}\right)$ leiti igale põllule valemiga

$$
K_{K}=\frac{P_{f}}{4 \sqrt{S}}
$$

kus $P_{f}$ on põllu tegelik ümbermõõt ja $S$ on pṍllu pindala. Ruudukujulise maatüki kompaktsuse koefitsient on üks ja mida ebakompaktsem on maatükk, seda suurem on vastav koefitsient.

Keskmine mulla boniteet $\left(B o n_{\mathrm{k}}\right)$ põldudele leiti digitaalse Eesti mullastiku kaardi andmete alusel. Selleks lõigati mullasti- ku kaarti põldude piiride kaardikihiga. Tekkinud polügoonide andmetel arvutati järgmise valemi abil igale põllule kaalutud keskmine mulla boniteet:

$$
\text { Bon }_{k}=\left(\sum \text { Bon }_{i} \times S_{i}\right) / \sum S_{i},
$$

kus $B o n_{i}$ on põllul oleva mullaerimi kontuuri boniteet ja $S_{i}$ selle erimi kontuuri pindala.

Põldudel oleva parandatud maa (maaparandussüsteemidega maa) osatähtsuse määramise aluseks oli maaparandussüsteemide piiride kaart, mida lõigati põldude piiride kaardiga. Tekkinud polügoonide pindade alusel arvutati ArcGIS-s päringuga iga põllu jaoks maaparandussüsteemide all olev pind $\left(S_{\text {maap }}\right)$. Põldudel oleva parandatud maa osatähtsus (Maap $\%_{6}$ ) arvutati valemiga

$$
\text { Maap }_{\%}=S_{\text {manp }} / S,
$$

kus $S$ on vastava põllukontuuri pind.

Neli näitajat (põllu kaugus Tartust, põllu kaugus lähimast asulast, põllu kaugus lähimast riigiteest ja põllu kaugus lähima naaberpõlluni) iseloomustasid põldude kaugusi teatud objektidest. Kaugused leiti ArcGISi vastava korraldusega Near, mis arvutab objektide vahel lühima vahemaa. Maa-ameti asustusüksuste kaart (seisuga 15.10.2017) oli aluseks linnade ja alevike piiride määramisel. Kaugused Tartu linnast on arvutatud linna piirist. Kauguste arvutamisel lähima asulani olid aluseks kõikide Tartu maakonna linnade ja alevike piirid. Iseloomustamaks põldude asukohti teedevõrgu suhtes, leiti kõigile põldudele kaugused lähima riigiteeni. Riigiteedena on siinkohal mõeldud põhi-, tugi- ja kõrvalmaanteid ja nende asukoha määramisel võeti aluseks vastavad ETAKi andmed (seisuga 2.07.2018). Iga põllu kaugus lähima naaberpõlluni leiti ühe kaardikihi (põllumassiivide digitaalkaart) andmetel. See kaardikiht oli samal ajal nii lähtekaardikihi (Input Features) kui ka lähimate objektide (Near Features) rollis. 
Maapinna konarlikkuse indeks arvutati põldudele Quantum GISi abil, kasutades funktsiooni Karedus. Selle funktsiooniga arvutab Quantum GIS Riley et al. (1999) poolt väljatöötatud maapinna kareduse indeksi (TRI - Terrain Ruggedness Index). Nimetatud indeks arvutatakse rastervormingus maapinna kõrgusmudeli andmetest ja ta arvestab iga piksli kaheksa naa- berpiksli kõrguste erinevust vastava piksli kõrgusest. Mida suurem on indeks, seda künklikuma maaga on tegemist. Indeks arvutati Maa-ameti maapinna kõrgusmudeli (TIF-vormingus rasterkaart, piksli suurus $10 \times 10$ meetrit) andmete alusel.

Tabel 1. Uuritud põldude ruumilisi omadusi iseloomustavate näitajate kirjeldav statistika (vaatluste arv oli 6604).

Table 1. Descriptive statistics of spatial properties of investigated arable land plots (number of observations was 6,604).

\begin{tabular}{lccccc}
\hline $\begin{array}{l}\text { Põlde iseloomustavad näitajad / } \\
\text { Characteristics of arable land plots }\end{array}$ & $\begin{array}{c}\text { Keskmine / } \\
\text { Average }\end{array}$ & $\begin{array}{c}\text { Mediaan / } \\
\text { Median }\end{array}$ & $\begin{array}{c}\text { Minimum / } \\
\text { Minimum }\end{array}$ & $\begin{array}{c}\text { Maksimum / } \\
\text { Maximum }\end{array}$ & $\begin{array}{c}\text { Standard- } \\
\text { hälve / SD }\end{array}$ \\
\hline $\begin{array}{l}\text { Pindala (ha) / } \\
\text { Area (ha) }\end{array}$ & 12,8 & 3,9 & 0,3 & 239,1 & 22,3 \\
$\begin{array}{l}\text { Kompaktsus / } \\
\text { Compactness }\end{array}$ & 1,4 & 1,3 & 0,9 & 6,8 & 0,4 \\
$\begin{array}{l}\text { Mulla boniteet / } \\
\text { Soil productivity }\end{array}$ & 44,5 & 45,0 & 20,1 & 64,0 & 5,7 \\
$\begin{array}{l}\text { Parandatud maa osatähtsus (\%) / } \\
\text { Ratio of ameliorated land (\%) }\end{array}$ & 50,2 & 60,7 & 0,0 & 100,0 & 47,4 \\
$\begin{array}{l}\text { Kaugus Tartust (km) / } \\
\text { Distance to Tartu city (km) }\end{array}$ & 17,7 & 16,7 & 0,0 & 42,5 & 9,5 \\
$\begin{array}{l}\text { Kaugus lähimast asulast (km) / } \\
\text { Distance to nearest settlement (km) }\end{array}$ & 4,2 & 3,5 & 0,0 & 15,7 & 3,2 \\
$\begin{array}{l}\text { Kaugus lähima riigiteeni (km) / } \\
\text { Distance to nearest main road (km) }\end{array}$ & 0,5 & 0,2 & 0,0 & 5,3 & 0,7 \\
$\begin{array}{l}\text { Kaugus lähima naaberpölluni (m) / } \\
\text { Distance to nearest neighbouring plot } \\
\text { (m) }\end{array}$ & 17,0 & 6,0 & 0,0 & 2370,0 & 62,1 \\
$\begin{array}{l}\text { Põldude konarlikkus / } \\
\text { Roughness of plots }\end{array}$ & 0,9 & 0,7 & 0,1 & 3,9 & 0,53 \\
\hline
\end{tabular}

Põldude pindalaline varieeruvus on suhteliselt suur, mida näitab ka standardhälve (tabel 1). Kuna Eestis haritakse ja kasutatakse põldusid pigem looduslikke piire kui katastripiiri järgides, siis pole nende kuju kõige kompaktsem. Tartumaa muldade viljakus on hea, üle Eesti keskmise, mis on 43 hindepunkti (Eesti mullastik, 2011). Lisaks viljakale mullale on ligikaudu pooled põllud kaetud maaparandussüsteemidega. Põldude keskmine kaugus Tartust on 17,7 $\mathrm{km}$. Eesti on kaetud tiheda teedevõrguga, see pärast on ka keskmine kaugus riigiteest üsna väike - $490 \mathrm{~m}$ (tabel 1). Põllud paiknevad üksteisega lähestikku, keskmine kaugus naaberpõlluni on vaid $17 \mathrm{~m}$. Samas on põlde, mis asuvad lähimast naabrist enam kui kahe kilomeetri kaugusel. Keskmine konarlikkuse indeks jääb alla ühe, mis näitab, et tegemist on tasase maa-alaga valitud pikslisuuruse juures. 


\section{4. etapp - Põldude uuritud omaduste mõju põldude võsastumisele}

Põldude mulla viljakuse, ruumiliste omaduste ja asukoha ning põldudel olevate võsastunud alade osatähtsuse vaheliste seoste uurimiseks kasutati kahte võtet. Esmalt jagati põllud kahte gruppi võsaga alade osatähtsuse järgi põldudel. Esimese grupi moodustasid põllud, kus võsaga alasid oli kuni viis protsenti (3980 põldu) ja neid põlde käsitleti kui võsata põlde. Võttes arvesse võsastumise määramise täpsust ja ebaselgeid alasid põldude servades, jäeti võsastumise alampiiriks viis protsenti. Teise grupi moodustasid põllud, kus võsaga alade osatähtsus oli üle viie protsendi (2624 põldu) ja neid loeti võsastunud põldudeks.

Seejärel leiti gruppidele põldude mulla viljakust, ruumilisi omadusi ja asukohta iseloomustavad keskmised näitajad ning hinnati nende näitajate varieeruvust ja erinevuste statistilist olulisust $t$-test'iga. Studenti $t$-väärtus (t-value) ja $p$-väärtus ( $p$-value) iseloomustavad I ja II grupi kohta arvutatud keskmiste näitajate erinevuse statistilist olulisust ja standardhälve (STD) vastavate andmete varieeruvust võrreldavates gruppides (tabel 2). Erinevatesse gruppidesse kuuluvate põldude ruumiliste omaduste võrdlemine võimaldab hinnata nende omaduste mõju põldude võimalikule võsastumisele. Lisaks koostati ka karp-vurrud diagrammid, mis illustreerivad võsata ja võsaga põlde iseloomustavate omaduste erinevusi.

Teiseks kasutati hüpoteesi (väiksema viljakusega, halvemate ruumiliste omadustega ja asukohaga põldudel on suurem tõenäosus, et nendel esineb võsastunud alasid) kontrollimiseks logistilist regressioonanalüüsi. See meetod võimaldab hinnata erinevate tegurite mõju mingi sündmuse toimumise tõenäosusele ehk teisisõnu: kui suur on tõenäosus, et mingi sündmus toimub. Selles töös oli binaarseks tunnuseks, mille toimumise võimalikku tõenäosust hinnati, võsa esinemine põllul. Nii nagu esimese võtte puhul (põldude grupeerimine kahte gruppi), loeti ka logistilise regressiooni korral põllud võsaga alla viie protsendi võsata põldudeks (sündmust ei toimunud ja binaarse tunnuse väärtus oli null). Kui põldudel oli võsa üle viie protsendi, siis sündmus toimus ja binaarse tunnuse väärtus oli üks.

Logistilise regressiooni mudeli üldkuju on järgmine:

$$
\operatorname{Logit}\left(p_{i}\right)=b_{0}+\sum\left(b_{i} x_{i}\right),
$$

kus $p_{i}$ on sündmuse toimumise tõenäosus; $b_{0}$ on võrrandi vabaliige; $b_{i}$ on regressioonikordaja ja $x_{i}$ on sündmuse toimumise tõenäosust mõjutava teguri väärtus. Logistilise regressioonanalüüsi tegemiseks ja mudeli headuse hindamiseks kasutati MS Exceli vabavaralist lisa The Real Statistics Resource Pack 6.0 (Zaiontz, 2019). Leidmaks, millised analüüsis uuritud omadused mõjutavad põldude võsastumist, kasutati samm-sammulist regressiooni (stepwise forward regression), mille käigus lisati järjest tunnuseid mudelisse. Lõplikku mudelisse jäid tegurid, mis olid statistiliselt olulised, selle hindamiseks kasutati $p$-väärtust ( $p$-value) ja šansside suhet. Mudeli headust hinnati ROC-kõvera (receiver operating characteristic curve) alla jääva pindala abil (AUC - area under the ROC curve), mis muutub vahemikus 0 kuni 1 . ROC-analüüsi ja ROC-kõverat kasutatakse ka logistilise regressiooniga saadud mudelite kvaliteedi ja prognoosi täpsuse hindamiseks. Mida suurem on AUC (ROC-kõvera alla jääv pindala), seda suurem on vastava mudeliga saadud prognoosi usaldusväärsus.

\section{Tulemused}

Lagedate ja võsaga põldude omaduste võrdlemise tulemused on esitatud tabelis 2. Valimis oli kokku 6604 põldu, millest 3980 olid lagedad ja 2624 esines võsa. I grupis on näidatud lagedaid põlde iseloomustavad keskmised näitajad ja II grupis vastavalt võsaga põlde iseloomustavad näitajad. 
Tabel 2. Lagedate ja võsaga põldude omaduste võrdlemine.

Table 2. Comparison of the characteristics of arable land plots without brushwood and with brushwood.

\begin{tabular}{|c|c|c|c|c|c|c|c|c|}
\hline \multirow{2}{*}{$\begin{array}{l}\text { Põlde iseloomustavad } \\
\text { näitajad / Characteristics } \\
\text { of arable land plots }\end{array}$} & \multicolumn{2}{|c|}{ Keskmine / Mean } & \multirow[b]{2}{*}{$t$} & \multirow[b]{2}{*}{$p$} & \multicolumn{2}{|c|}{$\begin{array}{c}\text { Standardhälve / } \\
\text { SD }\end{array}$} & \multirow{2}{*}{$\begin{array}{c}\text { F-ratio } \\
\text { Variances }\end{array}$} & \multirow[b]{2}{*}{$\stackrel{p}{p}$} \\
\hline & $\underset{\text { grupp/ }}{\text { group }}$ & $\underset{\text { II }}{\text { grupp/ }}$ & & & $\underset{\text { grupp/ }}{\text { group }}$ & $\underset{\text { grupp/ }}{\text { group }}$ & & \\
\hline $\begin{array}{l}\text { Pindala (ha) / } \\
\text { Area (ha) }\end{array}$ & 16,39 & 7,37 & 16,39 & 0,00 & 25,03 & 15,94 & 2,47 & 0,00 \\
\hline $\begin{array}{l}\text { Kompaktsus / } \\
\text { Compactness }\end{array}$ & 1,39 & 1,41 & $-2,30$ & 0,02 & 0,40 & 0,42 & 1,09 & 0,01 \\
\hline $\begin{array}{l}\text { Mulla boniteet/ } \\
\text { Soil productivity }\end{array}$ & 45,50 & 43,10 & 16,64 & 0,00 & 5,34 & 6,03 & 1,27 & 0,00 \\
\hline $\begin{array}{l}\text { Parandatud maa } \\
\text { osatähtsus (\%) / Ratio of } \\
\text { ameliorated land (\%) }\end{array}$ & 58 & 38 & 16,69 & 0,00 & 46,35 & 46,66 & 1,01 & 0,71 \\
\hline $\begin{array}{l}\text { Kaugus Tartust (km) / } \\
\text { Distance to Tartu city }(\mathrm{km})\end{array}$ & 16,70 & 19,30 & $-10,81$ & 0,00 & 9,47 & 9,40 & 1,01 & 0,69 \\
\hline $\begin{array}{l}\text { Kaugus lähimast asulast } \\
(\mathrm{km}) / \text { Distance to nearest } \\
\text { settlement }(\mathrm{km})\end{array}$ & 3,80 & 4,70 & $-10,97$ & 0,00 & 2,98 & 3,44 & 1,34 & 0,00 \\
\hline $\begin{array}{l}\text { Kaugus lähima riigiteeni } \\
(\mathrm{km}) / \text { Distance to nearest } \\
\text { main road }(\mathrm{km})\end{array}$ & 0,47 & 0,51 & $-2,35$ & 0,02 & 0,69 & 0,66 & 1,07 & 0,07 \\
\hline $\begin{array}{l}\text { Kaugus lähima } \\
\text { naaberpõlluni (m) / } \\
\text { Distance to nearest } \\
\text { neighbouring plot (m) }\end{array}$ & 12,80 & 23,30 & $-6,77$ & 0,00 & 44,74 & 81,20 & 3,29 & 0,00 \\
\hline $\begin{array}{l}\text { Põldude konarlikkus / } \\
\text { Roughness of plots }\end{array}$ & 0,80 & 0,95 & $-11,41$ & 0,00 & 0,47 & 0,59 & 1,55 & 0,00 \\
\hline
\end{tabular}

Tabeli 2 andmetest nähtub, et kõigi uuritud tegurite puhul on võsata ja võsaga põlde iseloomustavate näitajate keskmiste väärtuste erinevus statistiliselt oluline $(p \leq$ $0,05)$. Võsata ja võsaga põlde iseloomustavate näitajate erinevust illustreerib ka joonis 4. Sellel joonisel on toodud karp-vurrud diagrammid, mis iseloomustavad uuritud tegurite keskmisi väärtusi, keskmiste väärtuste standardvigu ja usalduspiire vastavalt võsata ja võsaga põldude grupis.

Tabeli 3 ja joonise 4 andmetest nähtub, et põldude keskmine pindala, mulla viljakuse (boniteet) ja põldudel oleva parandatud maa osatähtsuse erinevus on võsata ja võsaga põldude gruppide vahel kõige suurem. Keskmiselt on võsaga põldude pindala ligikaudu kaks korda väiksem kui võ- sata põldudel (osa A, joonis 4). Samuti on jooniselt (osa A) näha, et keskmine pindalade varieeruvus on mõlemas põldude suurusgrupis väike. Parandatud maa osatähtsus võsata põldudel oli ligikaudu 1,5 korda suurem kui võsaga põldudel (osa E, joonis 4). Parandatud maa osatähtsus võsaga põldudel oli keskmiselt 38 protsenti ja võsata põldudel oli sama näitaja 58 protsenti. Parandatud maa osatähtsuse varieerumine oli mõlemas põldude grupis samas suurusjärgus. Keskmise mulla viljakuse erinevus (boniteet) võsaga põldude ja võsata põldude gruppide vahel on 2,4 palli ja absoluutarvudes ei ole see väga suur. Võsaga põldude mulla boniteet oli 43,1 hindepunkti, jäädes alla Tartumaa keskmise mulla boniteedile, milleks on 44,5. 


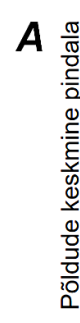

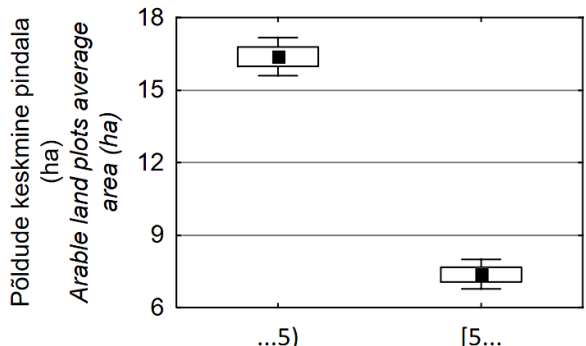

C

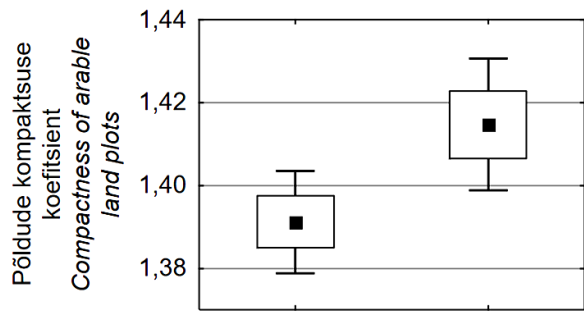

...5)

$[5 \ldots$

E

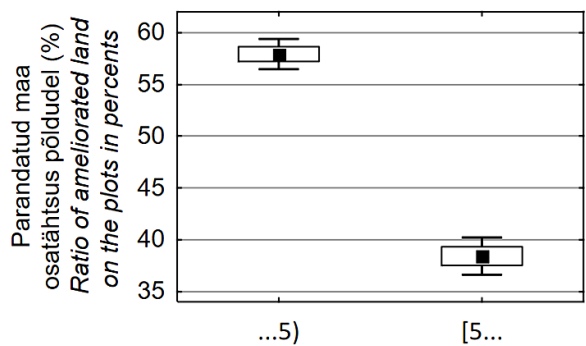

G

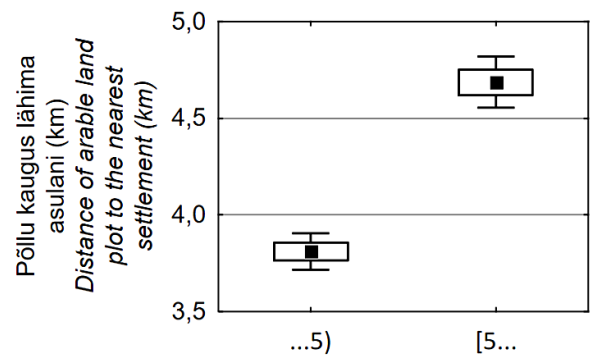

I

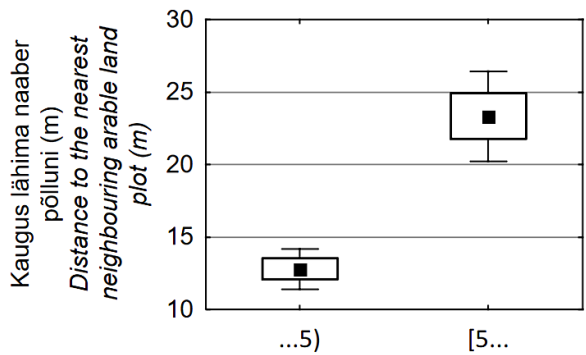

$B$

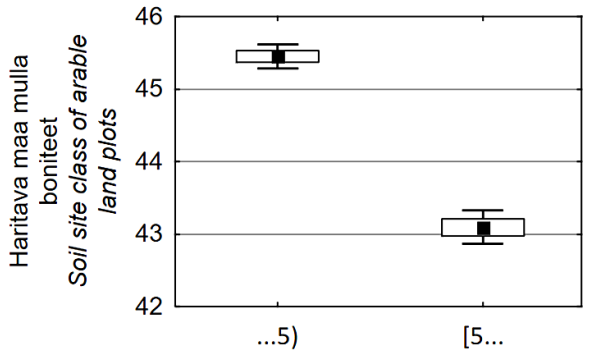

$D$

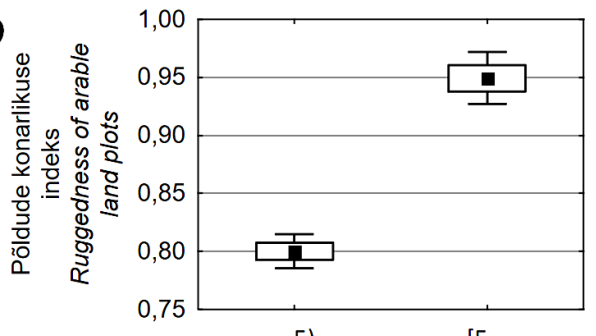

...5)

$[5 \ldots$

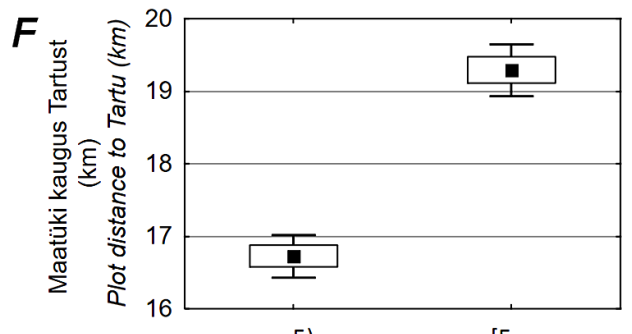

...5)

$[5 \ldots$

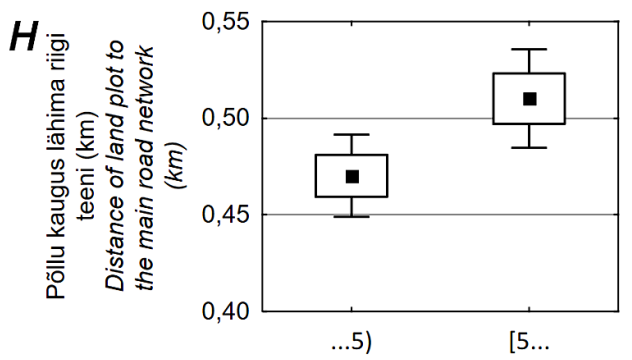

5) - võsa põldudel kuni 5 protsenti - brushwood on the plots up to 5 percents

[5 ... - võsa põldudel üle 5 protsendi - brushwood on the plots more than 5 percents

- Mean

$\square$ Mean \pm SE

I Mean $\pm 0,95$ Conf. Interval

Joonis 4. Kirjeldavate tunnuste keskväärtused lagedate ja võsaga põldudel.

Figure 4. Comparison of the characteristics of arable land plots without brushwood and with brushwood. 
Võsata põldude boniteet oli pisut üle maakonna keskmise, mis on 45,5 hindepunkti. Samas näitab joonise osa B siiski, et kahe põldude grupi keskmise mulla viljakuse erinevus on statistiliselt oluline.

Seost põldude asukoha (kaugus erinevatest objektidest) ja põldudel võsa esinemise vahel iseloomustavad joonise 4 osad F, G, H ja I. Võsaga põllud on Tartust ja lähimast asulast keskmiselt kaugemal kui võsata põllud - kaugused Tartust vastavalt 19,3 kilomeetrit ja 16,7 kilomeetrit ning kaugused lähimast asulast vastavalt 4,7 kilomeetrit ja 3,8 kilomeetrit. Põllu kaugus lähima naaberpõlluni oli võsaga põldudel keskmiselt 23,3 meetrit ja võsata põldudel 12,8 meetri. Absoluutarvudes on tegemist väikese erinevusega, aga keskmiste erinevus on siiski ligikaudu kahekordne. Kaugus lähima riigiteeni on võsata põldudel küll väiksem kui võsaga põldudel (osa H, joonis 4), kuid erinevus kahe grupi keskmiste vahel on ainult 0,04 kilomeetrit.
Põldude kuju iseloomustava kompaktsuse koefitsiendi keskmine väärtus võsata põldudel on väiksem kui võsaga põldudel, arvulised väärtused vastavalt 1,39 ja 1,41 (osa C, joonis 4). See tähendab, et keskmiselt on võsata põllud kompaktsemad kui võsaga põllud. Siiski on varieeruvus mõlemas põldude grupis suhteliselt suur ja võsata põldude kompaktsuse koefitsiendi keskmise usalduspiir kattub osaliselt võsaga põldude kompaktsuse koefitsiendi keskmise usalduspiiriga.

Joonis 4 (osa D) näitab, et võsaga põllud olid konarlikumad kui võsata põllud. Täiesti tasase maapinna konarlikkuse indeks oleks null. Võsaga põldude keskmine konarlikkuse indeks oli 0,95 ja võsata põldudel 0,80 . Seega on võsaga põldude konarlikkus ligikaudu 16\% suurem kui võsata põldudel. Ka oli võsaga põldude keskmine konarlikkuse varieeruvus suurem kui võsata põldudel.

Tabel 3. Logistilise regressiooni tulemused: mudeli parameetrite standardviga, statistiline olulisus ( $p$-väärtus) ning šansside suhe.

Table 3. Logistic regression results for the model: standard error (SE), statistical significance (p) and odds ratio of variables.

\begin{tabular}{lccc}
\hline $\begin{array}{l}\text { Põlde iseloomustavad näitajad / Characteristics of } \\
\text { arable land plots }\end{array}$ & $\begin{array}{c}\text { Standardviga / } \\
\text { SE }\end{array}$ & $p$ & $\begin{array}{c}\text { Šansside suhe / } \\
\text { Odds ratio }\end{array}$ \\
\hline Vabaliige / Intercept & 0,256 & 0,012 & 1,888 \\
Pindala (ha) / Area (ha) & 0,002 & 0,000 & 0,975 \\
Kompaktsus / Compactness & 0,078 & 0,000 & 2,260 \\
$\begin{array}{l}\text { Mulla boniteet / Soil productivity } \\
\text { Kaugus Tartust (km) / Distance to Tartu city (km) }\end{array}$ & 0,005 & 0,000 & 0,946 \\
$\begin{array}{l}\text { Kaugus lähimast asulast (km) / Distance to nearest } \\
\text { settlement (km) }\end{array}$ & 0,003 & 0,000 & 1,020 \\
$\begin{array}{l}\text { Kaugus lähima naaberpõlluni (m) / Distance to } \\
\text { nearest neighbouring plot (m) }\end{array}$ & 0,009 & 0,000 & 1,047 \\
$\begin{array}{l}\text { Põldude konarlikkus / } \\
\text { Roughness of plots }\end{array}$ & 0,053 & 0,001 & 1,002 \\
$\begin{array}{l}\text { Parandatud maa osatähtsus (\%) / } \\
\text { Ratio of ameliorated land (\%) }\end{array}$ & 0,058 & 0,000 & 1,294 \\
\hline
\end{tabular}

Model log likelihood ratio (LL) = 3987.26; AUC = 0.715; Adj. $\mathrm{R}^{2}=0.100 ;$ Significance at $p<0.05$. 
Logistilise regressiooni tulemusel koostatud lõpliku mudeli iseloomustus on toodud tabelis 3. Kasutades samm-sammulist regressiooni, lisati algul mudelisse kõik näitajad, mis iseloomustavad uuritud põlde. Selle tulemusena ilmnes, et põldude kaugus riigiteedest ei ole mudelis statistiliselt oluline $(p=0,196)$ ja seepärast jäeti nimetatud näitaja lõplikust mudelist välja.

Tabelis 3 kirjeldatud mudeli kõik argumenttunnused on statistiliselt olulised. Seda näitavad $p$-väärtused, mis kõik on väiksemad kui 0,05. Kolm argumenttunnust - põllu pindala, mulla keskmine boniteet põllul ja maaparanduse olemasolu põllul on negatiivselt seotud põldude võsastumise tõenäosusega (šansside suhe $<1$ ), mis tähendab, et nende argumenttunnuste suurenedes ühe ühiku võrra võsastumise tõenäosus väheneb. Ülejäänud argumenttunnused on positiivselt seotud põldude võsastumise tõenäosusega (šansside suhe $>1$ ), seega nende näitajate suurenedes suureneb ka põldude võsastumise tõenäosus.

Mudeli kirjeldusaste on suhteliselt madal (McFadden kohandatud $R^{2}=0,1$ (McFadden, 1974), tabel 3), kuid see on selliste ruumiliste uuringute puhul tavapärane (Müller \& Munroe, 2008). Mudeli headuse tervikhindamiseks kasutatud AUC (area under the curve) oli 0,72, mis tähendab, et koostatud mudel on võimeline eristama 72-protsendilise tõenäosusega võsata ja võsaga põlde. Vastavalt kokkuleppelistele piiridele (Kaart, 2012) loetakse rahuldavaks (fair) logistilised mudelid, mille AUC väärtused on vahemikus 0,70 ja 0,79.

\section{Arutelu}

Uuringu tulemuste põhjal selgus, et põldude võimalikku mahajätmist (võsa kasvamine põldudele) mõjutavad põllu pindala, boniteet, maaparanduse osatähtsus, kaugus Tartust, lähimast asulast, naaberpõllust ja põldude konarlikkus. Põldude keskmine kompaktsus ja keskmine kaugus riigiteedest oli võsaga ja võsata põldude gruppide vahel küll statistiliselt oluline, kuid antud tegurite puhul võib esineda olukord, kus toimuvad mõlemad protsessid -nii võsastumine kui ka aktiivne põllumajandustegevus.

Selle uuringu tulemustes ilmnenud seos põllu pindala ja võsastumise vahel on sarnane Abolina \& Luzadis (2015) poolt Lätis korraldatud uuringu tulemustele. Lätis hüljatakse enim põllumassiive pindalaga 5-10 hektarit ning kõige vähem pindalaga üle 20 hektari. Seega on Tartumaa põldudel toimuvad protsessid üsna sarnased Lätiga. Võsata põldude keskmine pindala oli 16,4 ha ja võsaga põldudel 7,4 ha.

Mullaviljakuse ja põllu võsastumise vahelisi seoseid on uurinud mitu teadlast (Benayas et al., 2007; Pointereau et al., 2008; Pazúr et al., 2014; Abolina et al., 2015). Madala viljakusega põllumaas nähakse potentsiaali metsakasvatuseks (Abolina \& Luzadis, 2015). Tihti on nii, et mitme erineva faktori koosmõju võib viia põllu võsastumiseni, näiteks kui madala viljakusega põllumassiiv on kevaditi liigniiske või ebakompaktse kujuga.

Maasikamäe \& Mandel (2015) leidsid Eesti 15 testpiirkonna alusel, et põllumassiivi kompaktsus mõjutab põllumajandusmaade võsastumist. Mida ebakompaktsema kujuga on põllumassiiv, seda enam on sellel võsa. Põllu ebakorrapärane kuju võib mõjutada tootmiseks tehtavaid kulutusi ning seetõttu ka vähendada tulu, mis võib viia põllu mahajätmiseni ja hilisema võsastumiseni (Sklenicka et al., 2014). Tartu maakonnas kompaktsuse seos võsastumisega nii selge ei olnud, mis näitab, et juhtumiuuringute tulemusi ei ole lihtne üldistada (van Vliet et al., 2015).

Eesti on Euroopa mõistes tasane maa ja konarlikkuse näitaja varieeruvus on üsna väike. Mida suurem see indeks on, seda keerulisema reljeefiga on tegemist. Täiesti tasase maa korral oleks see null. Tartu maakonna kontekstis iseloomustab konarlikkuse indeks pigem põllu mikroreljeefi - kas põld on tasane või pigem künklik. 
Konarlikkuse indeksil on oluline roll mulla erosiooni ja veerežiimi hindamisel (Zhao et al., 2016). Vihmavee aeglane äravool põllu lohkudest või mulla erosioon küngastelt võib viia maakasutuse muutuseni (Sikor et al., 2009), kus endisest põllumaast saab rohumaa või pikema aja möödudes võsaga kaetud ala.

Maaparanduse osatähtsus põllumassiivi pindalast pole väga levinud indikaator põldude võsastumist käsitlevates uurimustes. Üks põhjustest võib olla andmete kättesaadavus ja vähesus. Oletus, et enam võsastuvad põllud, kus maaparandus puudub või tema osatähtsus põllu pinnast on väike, leidis käesolevas uurimuses kinnitust. Kuid võib esineda ka vastupidist olukorda, kus kuivendatud ja küntud põllu maha jätmine hoopis soodustavad võsastumast, luues soodsad tingimused kiirekasvuliste puittaimede levikuks (Prishchepov et al., 2013).

Heterogeenne maastik on kasulik looduskeskkonna mitmekesisust silmas pidades, kuid põllumajandusliku maakasutuse seisukohast kipuvad üksteisest eraldatud põllud rohkem võsastuma kui lähestikku paiknevad põllud (Müller et al., 2009). Asukoht on oluline tegur, mis mõjutab maa kasutamise tingimusi. Lisaks kaugusele naaberpõllust on oluline ka ligipääsetavus. Kuna Eestis on tihe teedevõrk, siis kauguse mõju teedest ei mõjuta põldude võsastumist märkimisväärselt. Suuremat rolli võib mängida hoopis teede seisukord ja kandevõime, eriti just kevadisel ja sügisesel perioodil. Lisaks kaugusele teedest on mitu teadlast välja toonud kauguse mõju lähimast asulast või suuremast linnast (Pointereau et al., 2008; Prishchepov et al., 2013). Üldine tendents on, et kauguse suurenedes maade mahajätmine kasvab, kuid on ka vastupidiseid tulemusi (Hatna \& Bakker, 2011).

Selle uuringu tulemused iseloomustavad haritava maa mahajätmist ja seda mõjutavaid tegureid Tartu maakonnas. Ilma vastavate uuringuteta ei saa väita, et samasugused protsessid toimuvad ka mujal
Eestis. Seega oleks vaja teha analoogilised uuringud kogu Eesti kohta või vähemalt Eesti erinevate piirkondade kohta. Edasiste uuringute üks põhiküsimus on ka mahajäetud alade määramise metoodika täiustamine, kuna see ei ole päris selge. Taimkatte kõrgusmudel võimaldab määrata võsa ja muu puittaimestikuga alasid põldudel. Samas on olukordi, kus vahe võsastunud alade vahel on väike ja ortofotode visuaalse hindamise kogemuse järgi otsustades ei kasutata ka neid alasid, mis on üksteise lähedal asuvate võsaga alade vahel. Seega on võimalik, et mitte kasutatava haritava maa pind on suurem, kui on võsaga alade pind nendel põldudel. Kui näiteks 50\%-1 põllust on võsa, siis võib see tähendada, et pool põldu on endiselt kasutuses. Samas on ka võimalik, et kasutusest on väljas kogu põld, sest võsa paikneb väiksemate aladena kogu põllu ulatuses.

Tänusõnad. Autorid tänavad Tanel Kaarti statistika alaste konsultatsioonide eest.

\section{Kasutatud kirjandus}

Abolina, E., Luzadis, V.A. 2015. Abandoned agricultural land and its potential for short rotation woody crops in Latvia. - Land Use Policy, 49, 435-445.

Abolina, E., Volk, T.A., Lazdina, D. 2015. GIS based agricultural land availability assessment for the establishment of short rotation woody crops in Latvia. - Biomass and Bioenergy, 72, 263-272. https://doi.org/10.1016/j. biombioe.2014.10.026.

Alcantara, C., Kuemmerle, T., Baumann, M., Bragina, E.V., Griffiths, P., Hostert, P., Knorn, J., Müller, D., Prishchepov, A.V., Schierhorn, F., Sieber, A., Radeloff, V.C. 2013. Mapping the extent of abandoned farmland in Central and Eastern Europe using MODIS time series satellite data. - Environmental Research Letters, 8, No. 3. doi:10.1088/17489326/8/3/035035.

Benayas, J.M.R., Martins, A., Nicolau, J.M., Schulz, J.J. 2007. Abandonment of agricultural land: an overview of drivers and consequences. CAB Reviews: Perspectives in Agriculture, Veterinary Science, Nutrition and Natural Resources, 2, No. 057. https://doi. org/10.1079/PAVSNNR20072057. 
Cramer, V.A., Hobbs, R.J., Standish, R.J. 2008. What's new about old fields? Land abandonment and ecosystem assembly. Trends in Ecology \& Evolution, 23, 104-112. https://doi.org/10.1016/j.tree.2007.10.005.

Eesti mullastik. 2011. Estonian soils. (Eesti mullastik). - Eesti Entsüklopeedia. [WWW document]. - URL http://entsyklopeedia. ee/artikkel/eesti_mullastik. [Accessed 28 September 2018]. (In Estonian).

Eesti Statistika Andmebaas. 2011. Land use of agricultural households. (PMS403: Põllumajanduslike majapidamiste maakasutus). [WWW document]. - URL http:/ / pub.stat.ee/px-web.2001/Dialog/ Saveshow.asp. [Accessed 18 January 2019]. (In Estonian).

Eesti Statistika Andmebaas. 2017. Population as at 1 January according to gender, age group and county. (RV022: Rahvastik soo, vanuserühma ja maakonna järgi, 1 . jaanuar). [WWW document]. - URL http://pub.stat.ee/pxweb.2001/Dialog/Saveshow.asp. [Accessed 13 July 2018]. (In Estonian).

Filho, W.L., Mandel, M., Al-Amin, A.Q., Feher, A., Chiappetta Jabbour, C.J. 2017. An assessment of the causes and consequences of agricultural land abandonment in Europe. - International Journal of Sustainable Development \& World Ecology, 24, 554-560. https://doi.org/10.1080 /13504509.2016.1240113.

Gellrich, M., Zimmermann, N.E. 2007. Investigating the regional-scale pattern of agricultural land abandonment in the Swiss mountains: A spatial statistical modelling approach. - Landscape and Urban Planning, 79, 65-76. https://doi.org/10.1016/j. landurbplan.2006.03.004.

Hatna, E., Bakker, M.M. 2011. Abandonment and Expansion of Arable Land in Europe. Ecosystems, 14(5), 720-731.

Heil, E., Maltis, M. 2015. Real estate developments on cultivated areas in Tartumaa and the effects of the developments on land usage. (Tartumaa kinnisvaraarendused haritaval maal ja nende mõju haritava maa kasutamisele). - Master thesis. Tartu, Estonian University of Life Sciences. 58 pp.

Kaart, T. 2012. Analytical methods of binary variables. (Binaarsete tunnuste analüüsimeetodid). [WWW document]. - URL http:/ / ph.emu.ee/ ktanel/bin_tunnuste_ analyys/pt38.php. [Accessed 18 January 2019]. (In Estonian).

Larsson, S., Nilsson, C. 2005. A remote sensing methodology to assess the costs of preparing abandoned farmland for energy crop cultivation in northern Sweden. - Biomass and Bioenergy, 28, 1-6. https://doi.org/10.1016/j. biombioe.2004.05.003.
Levers, C., Schneider, M., Prishchepov, A.V., Estel, S., Kuemmerle, T. 2018. Spatial variation in determinants of agricultural land abandonment in Europe. - Science of The Total Environment, 644, 95-111. https://doi. org/10.1016/j.scitotenv.2018.06.326.

Maa-amet. 2018a. Market survey of cultivated area for 2017. (Haritava maa 2017. aasta turuülevaade). [WWW document]. - URL https:/ / www.maaamet.ee/sites/default/ files / content-editors/kinnisvara/haritava maa_2017_aasta_turuulevaade.pdf. [Accessed 14 September 2019]. (In Estonian).

Maa-amet. 2018b. Vegetation height model. (Taimkatte kõrgusmudel). [WWW document]. - URL https://geoportaal. maamet.ee/est/ Andmed-ja-kaardid/ Topograafilised-andmed/Korgusandmed/ Korgusmudelid-p508.html. [Accessed 18 January 2019]. (In Estonian).

Maasikamäe, S., Mandel, M. 2015. The impact of plot spatial properties on the conversion of arable land into brushwood. - Proceedings of the Annual 21st International Scientific Conference. Research for Rural Development, Latvia. Jelgava, 119-125.

MacDonald, D.D., Ingersoll, C.G., Berger, T.A. 2000. Development and evaluation of consensus-based sediment Quality guidelines for freshwater ecosystems. Archives of Environmental Contamination and Toxicology, 39, 20-31. https://doi. org/10.1007/s002440010075.

Massot, A. 2019. Common AgriculturalPolicy (CAP) and Treaty. (Ühine põllumajanduspoliitika (ÜPP) ja alusleping). [WWW document]. URL http://www.europarl.europa.eu/ftu/ pdf/et/FTU_3.2.1.pdf. [Accessed 18 January 2019]. (In Estonian).

McFadden, D. 1974. Conditional logit analysis of qualitative choice behavior. - Zarembka, P. (ed.). Frontiers in Econometrics. Berkeley California, Academic Press, 105-142.

Müller, D., Kuemmerle, T., Rusu, M., Griffiths, P. 2009. Lost in transition: determinants of postsocialist cropland abandonment in Romania. Journal of Land Use Science, 4(1-2), 109-129. https://doi.org/10.1080/17474230802645881.

Müller, D., Munroe, D.K. 2008. Changing rural landscapes in Albania: Cropland abandonment and forest clearing in the postsocialist transition. - Annals of the Association of American Geographers, 98, 855-876. https:/ / doi.org/10.1080/00045600802262323.

Pazúr, R., Lieskovský, J., Feranec, J., Ot'ahel', J. 2014. Spatial determinants of abandonment of largescale arable lands and managed grasslands in Slovakia during the periods of post-socialist transition and European Union accession. Applied Geography, 54, 118-128. https://doi. org/10.1016/j.apgeog.2014.07.014. 
Peterson, U., Aunap, R. 1998. Changes in agricultural land use in Estonia in the 1990s detected with multitemporal Landsat MSS imagery. - Landscape and Urban Planning, 41, 193-201.

Pointereau, P., Coulon, F., Girard, P., Lambotte, M., Stuczynski, T., Sánchez Ortega, V., Del Rio, A. 2008. Analysis of the driving forces behind farmland abandonment and the extent and location of agricultural areas that are actually abandoned or are in risk to be abandoned. JRC Scientific and Technical Reports. Institute for Environment and Sustainability. 204 pp.

Prishchepov, A.V., Müller, D., Dubinin, M., Baumann, M., Radeloff, V.C. 2013. Determinants of agricultural land abandonment in post-Soviet European Russia. - Land Use Policy, 30, 873-884. https://doi. org/10.1016/j.landusepol.2012.06.011.

Rasva, M. 2017. Concentration of Estonian agrcultural land use. (Põllumajandusliku makasutuse koondumine Eestis). (Magistritöö). - Master thesis. Tartu, Estonian University of Life Sciences. 85 pp. (In Estonian with English summary).

Riley, S.J., DeGloria, S.D., Elliot, R. 1999. A terrain ruggedness index that quantifies topographic heterogeneity. - Intermountain Journal of Sciences, 5(1-4), 23-27. (In Estonian with English summary).

Ritsoson, O. 2016. Changes in land use near Tartu on the examples of Haaslava, Tähtvere and Ülenurme municipalities comparing years 2005 and 2016. (Maakasutuse muutused Tartu linna ümbruses Haaslava, Tähtvere ja Ülenurme valla näitel võrreldes aastaid 2005 ja 2016). - Master thesis. Tartu, Estonian University of Life Sciences. 60 pp. (In Estonian with English summary).

Sikor, T., Müller, D., Stahl, J. 2009. Land fragmentation and cropland abandonment in Albania: Implications for the roles of state and community in post-socialist land consolidation. - World Development, 37(8), 1411-1423. https://doi.org/10.1016/j. worlddev.2008.08.013

Sklenicka, P., Janovska, V., Salek, M., Vlasak, J., Molnarova, K. 2014. The farmland rental paradox: Extreme land ownership fragmentation as a new form of land degradation. - Land Use Policy, 38, 587-593.

Statistikaamet. 2017. Tartu County. (Tartu maakond). [WWW document]. - URL http:// www.stat.ee/ppe-tartu-maakond. [Accessed 27 April 2017]. (In Estonian).

Zaiontz, C. 2019. Real statistics using Excel. [WWW document]. - URL www.real-statistics.com. [Accessed 22 March 2019].
Zaragozí, B., Rabasa, A., Rodríguez-Sala, J.J., Navarro, J.T., Belda, A., Ramón, A. 2012. Modelling farmland abandonment: A study combining GIS and data mining techniques. Agriculture, Ecosystems \& Environment, 155, 124-132.

Zhao, L., Huang, C., Wu, F. 2016. Effect of microrelief on water erosion and their changes during rainfall. - Earth Surface Processes and Landforms 41, 579-586. https://doi. org/10.1002/esp.3844.

Terres, J.-M., Scacchiafichi, L.N., Wania, A., Ambar, M., Anguiano, E., Buckwell, A., Coppola, A., Gocht, A., Källström, H.N., Pointereau, P., Strijker, D., Visek, L., Vranken, L., Zobena, A. 2015. Farmland abandonment in Europe: Identification of drivers and indicators, and development of a composite indicator of risk. - Land Use Policy, 49, 20-34. https://doi. org/10.1016/j.landusepol.2015.06.009.

Toetused. 2015. General requirements for receiving direct payments, single area payment, climate and environment payments and young farmer grant. (Otsetoetuste saamise üldised nõuded, ühtne pindalatoetus, kliima- ja keskkonnatoetus ning noore põllumajandustootja toetus). - Riigi Teataja, RT I, 29.12.2018, 15. (In Estonian).

Topograafilised andmed. 2014. Procedure of acquisition of topographic data and topographic features of general importance. (Topograafiliste andmete hõive kord ja üldist tähtsust omavad topograafilised nähtused). Riigi Teataja, RT I, 29.12.2013, 13. (In Estonian). van Vliet, J., de Groot, H.L.F., Rietveld, P., Verburg, P.H. 2015. Manifestations and underlying drivers of agricultural land use change in Europe. - Landscape and Urban Planning, 133, 24-36. https://doi.org/10.1016/j. landurbplan.2014.09.001.

Veeroja, P., Heil, E., Maltis, M., Maasikamäe, S. 2013. Impact of discrete new real estate developments on the spatial properties of arable land. - Rural Development 2013: The Sixth International Scientific Conference Rural Development 2013, Lithuania, November, 2013. Aleksandras Stulginskis University, Akademija (3), 501-506.

Verburg, P.H., van Berkel, D.B., van Doorn, A.M., van Eupen, M., van den Heiligenberg, H.A.R.M. 2010. Trajectories of land use change in Europe: a model-based exploration of rural futures. - Landscape Ecology, 25(2), 217-232. https://doi.org/10.1007/s10980-009-9347-7.

Virma, F. (2004). Land relations, land use and land management in Estonia. (Maasuhted, maakasutus ja maakorraldus Eestis). Tartu, Halo. 339 pp. (In Estonian). 


\section{Land abandonment in Tartu County}

\section{Merit Mandel, Siim Maasikamäe and Mait Lang}

\section{Summary}

We estimated agricultural land abandonment in Tartu County, Estonia. The study was based on a combination of the Estonian National Topographic Database vector data and land cover height model raster data. The study period covered a timeframe from 2011 to 2017. Our dataset consisted of 6,604 agricultural plots. Nine spatially explicit variables (area of the plot, compactness, soil productivity, ratio of ameliorated land, distance to Tartu city, distance to the nearest settlement, distance to the nearest main road, distance to the nearest neighbouring plot and roughness of plots) were studied to detect land abandonment. The purpose of this study was to evaluate the potential impact of soil productivity, spatial characteristics and the location of agricultural land on the abandonment of arable land. The hypothesis was that the lower the productivity, inferior spatial characteristics and location of the field, the greater the probability that the field will have overgrown areas and be abandoned.

The study had four stages. In the first stage, a digital map of the agricultural plots was prepared. The second stage was to determine abandoned areas in the agricultural fields using laser scanning data. The percentage of abandonment per field was found as a result of the second stage. The third step was to characterize the spatial characteristics (e.g. size, shape, etc.) of the agricultural plots. The fourth stage involved a statistical analysis of the data to investigate the relationship between land abandonment and field characteristics. Two approaches were used to investigate the relationship between soil productivity, spatial characteristics and location of plots and the extent of abandonment in the agricultural fields. First, the fields were divided into two groups according to the proportion of brushed areas in the fields. The first group consisted of fields with brushed areas of up to five percent (3,980 fields) and these fields were treated as non-abandoned fields. Taking into account the accuracy of the determination of the brushwood and the uncertain areas at the edges of the fields, the minimum limit was kept at five percent. The second group consisted of fields where brushed areas accounted for more than five percent $(2,624$ fields) and were considered as abandoned fields. In order to compare the two groups, mean values of the field characteristics were calculated and we evaluated the variability and statistical significance of the difference by $t$-test. Student's $t$-value and $p$-value characterize the statistical significance of the difference between the mean values calculated for groups I and II and the variability of the standard deviation (STD) data in the comparable groups (Table 3). Comparison of the spatial characteristics of fields belonging to different groups enables to evaluate the influence of these properties on possible abandonment. In addition, box-whiskers diagrams were drawn to illustrate the differences in the characteristics of non-abandoned and abandoned fields. The second, logistic regression analysis was used to test the hypothesis. This method allows evaluating the effect of different factors on the likelihood that an event will occur. In this research, the presence of brushed areas in the field was a binary trait the probability of occurrence of which was estimated. As in the first approach (grouping of fields into 
two groups), in logistic regression, fields with brushed areas of up to five percent (no event occurred) and the value of the binary variable was zero. If the fields had brushed areas of more than five percent, the event occurred and the value of the binary variable was one.

The result of the first approach showed the difference in all mean values of the two investigated group characteristics $(p \leq$ $0.05)$. As a result of the logistic regression, three variables (plot area, soil productivity and the ratio of ameliorated land) were negatively related to the likelihood of abandonment (odds ratio < 1 ), which means that as these arguments increase by one unit, the likelihood of abandonment decreases. The rest of the argument features were positively related to the probability of field abandonment (odds ratio $>1$ ); as these parameters increase, the probability of field abandonment increases. Even if the McFadden's adjusted $R^{2}=0.1$ (McFadden, 1974) was low, this is common in such spatial studies (Müller \& Munroe, 2008). The AUC (area under the curve) used for the overall assessment of model goodness was 0.72. Logistic models with AUC values between 0.70 and 0.79 are considered as a fair result. 